\title{
Constraints and Suggested Strategy for Creating Better Performance in Agriculture Development by the Heads of Panchayat Raj Institutions
}

\author{
Kavita B. Khade ${ }^{1}$, P. A. Ghadage ${ }^{2 *}$, R. B. Kalamkar ${ }^{3}$ and V. G. Patil ${ }^{4}$ \\ Department of Extension Education, College of Agriculture, Dr. BSKKV, \\ Dapoli-415712, India \\ Department of Agricultural Extension and Communication, M.P.K.V., Rahuri -413722, India \\ *Corresponding author
}

\section{A B S T R A C T}

\begin{tabular}{|l|}
\hline K e y w o r d s \\
Constraints, \\
Strategy, \\
Performance, \\
Agriculture \\
Development, \\
Heads of Panchayat \\
Raj Institutions \\
\hline Article Info \\
\hline Accepted: \\
26 May 2020 \\
Available Online: \\
10 June 2020 \\
\hline
\end{tabular}

The present study was conducted in Ratnagiri district of Maharashtra. All nine tahsils of Ratnagiri district were selected for the study. Ten Grampanchayat were selected by random sampling method from each of tahsils of Ratnagiri district. Considering the objectives and other aspects of the study, it was decided to study the heads of Panchayat Raj Institutions currently working in the office. Thus, one President of Zilla Parishad, Nine Panchayat Samiti Sabhapati and Ninety Gram Panchayat Sarpanch were the respondents for the study. The data were collected with the help of structured interview schedule. Personal technique was used for data collection. Thus the total sample size was 100. "Lack of technical and service support from development agencies" (78.00 per cent), was the major constraint in their day to day work, followed by "high cost of agricultural inputs" (76.00 per cent), and "lack of information about development scheme" (74.00 per cent). Majority (78.00 per cent) of heads of panchayat raj institutions suggested "economically weaker section should be the only criteria for benefits of various schemes", followed by "need of orientation and frequent refresher training for playing a active and responsible role" (76.00 per cent), "considering the geographical conditions of Konkan there is need for enhancement of grants for all schemes" (75.00 per cent), and "timely allotment of funds and subsidy" (74.00 per cent).

\section{Introduction}

The Panchayat Raj has come into existence with the sole aim of decentralization of government power for the welfare of the rural people. After independence, the Panchayat Raj has become a back bone of Indian democracy. In the three tier system of Panchayat Raj, the non-officials are playing an important role in establishing linkages between officials and the beneficiaries. The local self-government institutions are expected to plan and implement the programmes for rural, agriculture, horticulture and allied sectors.

However, the line of resistance between a villagers and an officer is hard. Therefore it is expected that knowledge on programmes of rural and agriculture development should infiltrate through non-official who is nearer and dearer to the villagers, who is at the grass 
root level of community development by providing assistance. Heads elected to the various Panchayat Raj Institutions are therefore very important because they are not politically influential, but because they are direct carriers of knowledge of rural and agricultural development programmes, rural people are convinced to a greater extent by them.

Further, no development can take place unless there is active participation of the people. Heads of PRIs by getting proper support from their Panchayat members shall involve the farmer in the process of rural and agriculture development. The officials of various line departments are catalytic agents only. They are important, no doubt, but more important are peoples' representatives.

On the back drop of the foregoing discussion, it becomes clear that the elected Heads of Panchayat Raj Institutions could play a significant role in around development programmes.

However, their success and efficiency depends upon the Leadership Pattern in taking favorable decisions in favour of farmers and based on the knowledge possessed by them about rural development. This aspect of leadership and their role in rural and agriculture development has not been studied so far, comprehensively, especially in Maharashtra state. The present study has been undertaken with the following specific objectives include to find out the constraints being faced by the heads of panchayat raj institutions in agriculture development. And also to suggest strategy for creating better performance of panchayat raj institution.

\section{Materials and Methods}

The present study was conducted in Ratnagiri district, Konkan region of Maharashtra state. All nine tahsils of Ratnagiri district were selected for the study. Ten Grampanchayat were selected by random sampling method from each of tahsils of Ratnagiri district. Considering the objectives and other aspects of the study, it was decided to study the heads of Panchayat Raj Institutions currently working in the office.

In Ratnagiri district there is one president of Zilla Parishad, 9 Panchayat Samiti Sabhapati and 837 Gram Panchayat Sarpanch. Thus, one President of Zilla Parishad, Nine Panchayat Samiti Sabhapati and Ninety Gram Panchayat Sarpanch were the respondents for the study. Thus, the total sample size was 100. The Expost facto research design was used for the study. The data were collected by the investigator herself with the structured interview schedule developed for the study.

Collected data were processed and converted into suitable statistical methods such as frequency, percentage, correlation analysis and multiple regressions.

\section{Results and Discussion}

Constraints being faced by the heads of panchayat raj institutions in agriculture development

An important aspect of the study was to identify the constraints operating against their working in Panchayat Raj. An enquiry was made with the heads of Panchayat Raj Institutions about the constraints in agriculture development. The important constraints as stated by the heads of Panchayat Raj Institutions are given in Table 1. The analysis of findings regarding constraints faced by the heads of panchayat raj institutions revealed that "lack of technical and service support from development agencies" (78.00 per cent), was the major constraints in agriculture development, followed by "high cost of agricultural inputs' (76.00 per cent), 'lack of information about 
development scheme" (74.00 per cent) and "lack of peoples participation" (72.00 per cent).

"Inadequate funds as well as subsidy for various development schemes" were also reported by 70.00 per cent heads of panchayat raj institutions, "Lack of co-operation from Panchayat Samiti and Zilla Parishad" and "time consuming documentation work" were two important constraints opined by 68.00 per cent and 66.00 per cent heads of panchayat raj institutions, respectively.

"Poor infrastructural facilities" and "Groupism among the villagers" were the hurdles reported by more than sixty per cent heads of panchayat raj institutions.

Whereas no after sale service in energy development scheme which is important constraints reported by 60.00 per cent respondents in agriculture development.

Constraints in day to day work as disincentives for the heads of Panchayat Raj Institutions and ultimately reduce their efficiency and target oriented work. Some of the severe constraints have been brought forward by the heads of Panchayat Raj Institutions. By establishing a close coordination among three tiers of Panchayat Raj with service and policy support and farming community, these constrains could be overcome. The findings of the present study are in line with Shirke et al., (2001) and dissimilar with the Tawade et al., (1995), Jayalaxmi (1997).

\section{Suggested strategy for creating better performance of heads in panchayat raj institution}

Various strategic suggestions made by the heads of Panchayat Raj Institutions for their better performance in Panchayat Raj are presented in Table 2.

The information furnished in Table 2 with respect to strategic suggestions indicated that, "economically weaker section should be the only criteria for benefits of various schemes" as suggested by majority (78.00 per cent ) of heads of panchayat raj institutions, followed by "need of orientation and frequent refresher trainings for playing a active and responsible role" (76.00 per cent), "considering the geographical conditions of Konkan there is need for enhancement of grants for all schemes" (75.00 per cent), and "timely allotment of funds and subsidy" (74.00 per cent). Whereas 73.00 per cent of them suggested that "Government should motivate people for their self income generating activities" by policy support and Government should provide special grants for transfer of technology of agricultural development (72.00 per cent).

Further more than sixty per cent suggested that "Supporting staff with Gramsevak for every Grampanchayat" (68.00 per cent), "timely and adequate co-operation from Panchayat Samiti and Zilla Parishad" (67.00 per cent), "need of technical support from Konkan Krishi Vidyapeeth" (66.00 per cent), and "Government should think about less paper work" (64.00 per cent) were important strategic suggestions for their better performance in panchayat raj institutions.

The success of the Panchayat Raj Institutions as a development organization shall depend on the extent to which it can involve different sections of village people.

For every development activity there is need of funds, most of the times government allots equal funds to all the panchayats. 
Table.1 Constraints being faced by the heads of panchayat raj institutions in agriculture development

\begin{tabular}{|c|c|c|c|}
\hline \multirow{2}{*}{$\begin{array}{l}\text { Sl. } \\
\text { No. }\end{array}$} & \multirow[t]{2}{*}{ Constraints } & \multicolumn{2}{|c|}{ Respondents } \\
\hline & & $\begin{array}{c}\text { Frequency }(n= \\
100)\end{array}$ & $\begin{array}{l}\text { Percenta } \\
\text { ge }\end{array}$ \\
\hline 1 & $\begin{array}{l}\text { Lack of technical and service support from development } \\
\text { agencies }\end{array}$ & 78 & 78.00 \\
\hline 2 & High cost of agricultural inputs & 76 & 76.00 \\
\hline 3 & Lack of information about development scheme & 74 & 74.00 \\
\hline 4 & Lack of peoples participation & 72 & 72.00 \\
\hline 5 & Inadequate funds as well as subsidy & 70 & 70.00 \\
\hline 6 & $\begin{array}{l}\text { Lack of co-operation from Panchayat Samiti and Zilla } \\
\text { Parishad }\end{array}$ & 68 & 68.00 \\
\hline 7 & Time consuming documentation work & 66 & 66.00 \\
\hline 8 & Poor infrastructural facilities & 64 & 64.00 \\
\hline 9 & Groupism among the villagers & 62 & 62.00 \\
\hline 10 & No after sale service in energy development scheme & 60 & 60.00 \\
\hline
\end{tabular}

Table.2 Suggested strategic suggestions for better performance of heads in Panchayat Raj Institutions

\begin{tabular}{|c|c|c|c|}
\hline \multirow{2}{*}{$\begin{array}{l}\text { Sl. } \\
\text { N } \\
\text { o. }\end{array}$} & \multirow[t]{2}{*}{ Suggestions } & \multicolumn{2}{|c|}{ Respondents } \\
\hline & & $\begin{array}{l}\text { Frequency }(n= \\
100)\end{array}$ & $\begin{array}{l}\text { Percenta } \\
\text { ge }\end{array}$ \\
\hline 1 & $\begin{array}{l}\text { Economically weaker section should be the only criteria } \\
\text { for benefits of various schemes }\end{array}$ & 78 & 78.00 \\
\hline 2 & $\begin{array}{l}\text { Need of orientation and frequent refresher trainings for } \\
\text { playing a active and responsible role }\end{array}$ & 76 & 76.00 \\
\hline 3 & $\begin{array}{l}\text { Considering the geographical conditions of Konkan there } \\
\text { is need for enhancement of grants for all schemes }\end{array}$ & 75 & 75.00 \\
\hline 4 & Timely allotment of funds and subsidy & 74 & 74.00 \\
\hline 5 & $\begin{array}{l}\text { Government should motivate people for their self income } \\
\text { generating activities by policy support }\end{array}$ & 73 & 73.00 \\
\hline 6 & $\begin{array}{l}\text { Government should provide special grants for transfer of } \\
\text { technology of agricultural / rural development }\end{array}$ & 72 & 72.00 \\
\hline 7 & $\begin{array}{l}\text { Supporting staff with Gramsevak for every } \\
\text { Grampanchayat }\end{array}$ & 68 & 68.00 \\
\hline 8 & $\begin{array}{l}\text { Timely and adequate co-operation from Panchayat Samiti } \\
\text { and Zilla Parishad }\end{array}$ & 67 & 67.00 \\
\hline 9 & $\begin{array}{l}\text { Need of technical support from Konkan Krishi } \\
\text { Vidyapeeth }\end{array}$ & 66 & 66.00 \\
\hline 10 & Government should think about less paper work & 64 & 64.00 \\
\hline
\end{tabular}


Training is an important component for developing managerial ability of the heads, hence proper orientation and refresher training to newly elected members and office bearer is needed. The heads of Panchayat Raj Institutions are very much keen and interested in the welfare of farmers, hence they had offered strategic suggestions which need policy support.

The analysis of findings regarding constraints faced by the heads of panchayat raj institutions revealed that "lack of technical and service support from development agencies" (78.00 per cent), was the major constraints in their day to day work, followed by 'high cost of agricultural inputs' (76.00 per cent), 'lack of information about development scheme" (74.00 per cent) and "lack of peoples participation" (72.00 per cent).

"Inadequate funds as well as subsidy for various development schemes" were also reported by 74.00 per cent heads of panchayat raj institutions, "Lack of co-operation from Panchayat Samiti and Zilla Parishad" and "time consuming documentation work" were two important constraints opined by 68.00 per cent and 66.00 per cent heads of panchayat raj institutions, respectively. "Poor infrastructural facilities" and "Groupism among the villagers" were other constraints reported by more than sixty per cent heads of panchayat raj institutions.

The findings with respect to strategic suggestions indicated that, "economically weaker section should be the only criteria for benefits of various schemes" as suggested by majority (78.00 per cent heads of panchayat raj institutions followed by "need of orientation and frequent refresher training for plying a active and responsible role" (76.00 per cent), "considering the geographical conditions of Konkan there is need for enhancement of grants for all schemes" (75.00 per cent), and "timely allotment of funds and subsidy" (74.00 per cent). Whereas 73.00 per cent each of them suggested that "Government should motivate people for their self-income generating activities" by policy support and Government should provide special grants for transfer of technology of agricultural development (72.00 per cent).

Further more than sixty per cent suggested that "Supporting staff with Gramsevak for every Grampanchayat" (68.00 per cent), "timely and adequate co-operation from Panchayat Samiti and Zilla Parishad" (67.00 per cent), "need of technical support from Konkan Krishi Vidyapeeth" (66.00 per cent), "Government should think about less paper work" (64.00 per cent) were important strategic suggestions for their better performance in panchayat raj institutions.

\section{References}

Bhugul, M. K., Chinchmalatpure U.R. and Katole R.T. (2011). Pattern of internet use by agricultural students.' Abstract $6^{\text {th }}$ national Extension Education Congress, held at Goa Dec.17-19. (236).

Chaudhary, R. R., MamtaMokale, P. S. Shinde, and R. S. Bhopale., (2004). Role performance by women members in gram panchayat. Rural India (January, 2004), pp. 3-5.

DevdasRajammal, P. (1998). Training women for political participation in the local bodies. Research highlights, JADU, 8 (1):1-5.

Gajre, B. M., (1997). A study of role perception and performance of gram panchayat members from Haveli taluka of Pune district. M. Sc. (Agri.) Thesis, Mahatma Phule Krishi Vidyapeeth, Rahuri.

Jayalaxmi, K. (1997). Empowerment of 
women in Panchayats-Experiences of Andhra Pradesh. Journal of Rural Development., 16(2): 371.

KanasePallavi, (2012). Media use and utilization by women members of PRI's for seeking information on rural development. M.Sc. (Agri.) Thesis, Dr. BalasahebSawantKonkan Krishi Vidyapeeth, Dapoli.

Kiranmayee, J.R. (1997). A study on characteristics and role performance of leaders working under podupulakshmi scheme in Nellore district of Andhra Pradesh. Abstract - The Journal of Research, Achary N. G. Ranga Agriculture University, Hyderabad.25(1):85.

Mukharji, N., (1994). Self government and its instrumentalities. Economics and political weekly, 29 (14): 789-792.

Nirmal, Kumar. (2003). Dissemination of farm information through mass media. Maharashtra journal of Extension Education, 22 (2): 10-15.

Pai, S. (1998). Pradhan in new Panchayats field notes from Meerut district. Economics and political weekly, May 2, pp. 1009-1010.

Patil, S.T., (1999). A study of role performance of women members in panchayat raj institutions in Ratnagiri district. M.Sc. (Agri.) Thesis, Dr. Balasaheb Sawant Konkan Krishi Vidyapeeth, Dapoli.

PujariVarsha., (2006). A study on training needs of panchayat women members in Ratnagiri district. M. Sc. (Agri.) Thesis,
Dr. Balasaheb Sawant Konkan Krishi Vidyapeeth, Dapoli.

Shirke V. S., G. K. Sawant (2001). Role performance and problems encountered by rural local leaders in agricultural development. Maharashtra Journal of Extension Education, XX: 97-99.

Subha, K. (1995). Training: an aid to empower rural women leaders. Kuruskhetra, April, 43 (7):99-100.

Tawde N. D., A. J. Nirban and S. B. Shinde (1995). Constraints of local leaders in relation to their agriculture development activities. Maharashtra Journal of Extension Education, Vol.XIV: 235238.

Tyagi, L. K., Sinha, B. P. and Singh, R., (2002). Leadership styles and development functioning of panchayat bureaucracy. Rajasthan Journal of Extension Education., pp. 17-22.

Upadhyay Rajashree, Priyanka Chauhan and Bhupendra Upadhyay. (2003). Women in local governance: emerging dimensions. $1^{\text {st }}$ National Extension Education Congress September 12-14, 2003, Society of Extension Education, Agra.

Valunj, D. R., (1997). A study of role performance of gram panchayat members in village development activities in Ambegaontaluka of Pune district. M. Sc. (Agri.) Thesis, Mahatma Phule Krishi Vidyapeeth, Rahuri.

Vithal, C. P., (1998). Devolution of powers and functions to panchayat raj Institutions. Kurukshetra, 47: 8-12.

\section{How to cite this article:}

Kavita B. Khade, P. A. Ghadage, R. B. Kalamkar and Patil, V. G. 2020. Constraints and Suggested Strategy for Creating Better Performance in Agriculture Development by the Heads of Panchayat Raj Institutions. Int.J.Curr.Microbiol.App.Sci. 9(06): 3775-3780. doi: https://doi.org/10.20546/ijcmas.2020.906.447 